\title{
Influence of mammal fossorial activity on bearing-out some chemical elements on up of soil cover
}

\author{
Olexandr Pakhomov ${ }^{1}$ - Oleg Didur ${ }^{2}$ - Iryna Loza ${ }^{2}$ \\ ${ }^{1}$ Department of Zoology and Ecology, Biology, Ecology and Medicine Faculty, Dnepropetrovsk National \\ University, Gagarina av., 72, 49010 Dnepropetrovsk. Ukraine \\ ${ }^{2}$ Institute of Biology, Dnepropetrovsk National University, Gagarina av., 72, 49010 Dnepropetrovsk. \\ Ukraine, e-mail: irinaloza@hotmail.com; didur@ua.fm
}

Keywords: fossorial activity, mammals, migration of micro- and macroelements, biological cycle.

\section{SUMMARY}

Fossorial activity of mammals is conductive to trace of microelements from more deep soil horizons into zone of its active involving to biological cycle. As a result of researches have established the mostly intensive migration of micro-and macroelements that is goes at the expense of mammals fossorial activity it is typical for humid gully lime-and-ash with oak wood. A middle position in speed of entering chemical elements is belonging to artificial oak wood in the watershed and humid lime-and-ash with oak wood in floodplain. Mostly slow migration in speed of entering elements is typical for middle-dry pine wood on sandy terrace.

\section{INTRODUCTION}

Due to animal fossorial activity many chemical elements and its compositions migrate from deep soil horizons onto soil cover and more intensively involve in biological cycle of matter. This way of animal activity was note by Levakovsky in the end of 19 century. Vernadsky also wrote about it. In XX century investigation of animal fossorial activity was one of most way in ground zoology and biogeocoenotical researches (Grulich, 1958; Абатуров, 1984; Абатуров, Карпачевский 1966а; Абатуров и др., 1969). The special attention scientists paid to migration of heavy metals and radionuklides (Pakhomov, Belokon, 1996; Пахомов, Подьячева, Галкин, 1998). On that time an important fact for processes of soil genesis and function of soil safely mechanisms was established: impact of fossorial activity to processes of soil desalinization (Иванов, 1950; Зубкова, 1975; Абатуров, 1984).

Animal influence on chemical characteristics shows often in process of transport soil matter, intensification of organic matter decomposition under the influence of physical and chemical regime changes which promote for soil richness by humus.

As a result a fossorial activity of animals is mixing topsoil humus layer with subsoil which is situated more deeply. Thanks to this process subsoil becomes richer by organic matter (Гиляров, 1951; Кучерук, 1963; Reva et. all, 1996; Пахомов, 1997a). Fossorial activity has an influence to soil pH, contents of phosphorus, nitrogen, potassium and to ion absorption by plants (Koide et al., 1987; Carlson, White, 1988; Pakhomov, Bulakhov, 1995).

\section{MATERIALS AND METHODS}

As a base for researches was choose following different types of native and artificial forests which situate in Steppe Pridneprov'ye: humid gully lime-and-ash with oak wood, artificial oak wood in the watershed, humid lime-and-ash with oak wood in floodplain, middle-dry pine wood on sandy terrace. In these conditions was investigated fossorial activity of different fossorial mammals as mole-rat, mice and mole. Gophers and mole-rats were more active in condition of steppe ecosystems. In forest ecosystems (gully oak-wood and in artificial wood in watershed) lives a mole-rat, in floodplain oak woods dwells a mole.

For achievement of mammals fossorial activity influence on edaphotopes the comparative method has used that consist in the determination the quantity of micro- and macroelements. Soil samples were taken at sites with fossorial activity and at sites without this activity (as a control). Soil samples were taken in six-multiple recurring.

\section{RESULTS AND DISCUSSION}

Fossorial activity conductive to trace of some chemical elements and its compositions on surface that is conductive to active involving in biological cycle different micro- and macroelements (Пахомов, 1992; Pakhomov, Bulakhov, 1995; Bulakhov, 1997; Pakhomov, 1997, 1997a).

As is well known chemical structure of soil determines its physical and chemical properties and stipulates for grow and development vegetation. Microelements which are consisted in soil participate in process of plants physiological adaptation and its stable against unfavourable factors of environment. 
Specific character of mammal fossorial activity and place of its dwelling have an influence to quantity of microelements which were on upper soil layer. Mechanical influence of fossorial mammals is connected with construction a lot of burrows and holes, voids and cavities that are formed specific hydrothermal and air regimes into the soil. As well as go on the tracing a soil matter from deep horizons on top and mixing it with vegetative substrate and animals excrements. In these conditions the new relief of soil profile is formed which consist of micro loftiness look as small piles of ground. Ground matter which was traced by mammals consists from different chemical elements and its organic and mineral compositions which are redistributed into soil profile.

It has been established that middle quantity of researched elements in points under fossorial activity is similar with control points. The points with mice fossorial activity in condition of humid gully lime-and-ash with oak wood are other for this index. In these conditions quantity of iron and magnesium was exceed quantity of these elements in control soil (Table 1). In artificial wood with oak in watershed containing of magnesium at points with fossorial activity of mole-rat also exceeded the control.

Entering of chemical elements with ground activity of mammals in different types of steppe woods

Table 1.

\begin{tabular}{|c|c|c|c|c|}
\hline \multirow[t]{3}{*}{ Mammals specie } & \multirow[t]{3}{*}{ Chemical element } & \multicolumn{2}{|c|}{ Middle quantity of element } & \multirow{2}{*}{$\begin{array}{c}\text { Total entering of element for } 1 \\
\text { year at the expense of soil } \\
\text { rejections }\end{array}$} \\
\hline & & $\begin{array}{l}\text { Soil with fossorial activity } \\
\text { (experiment) }\end{array}$ & $\begin{array}{l}\text { Soil layer } 0-10 \mathrm{~cm} \\
\text { (control) }\end{array}$ & \\
\hline & & \multicolumn{2}{|c|}{$\mathrm{mmol} / \mathrm{kg}$ of soil } & $\mathrm{mmol} / \mathrm{ha}$ per a year \\
\hline \multicolumn{5}{|c|}{ Humid gully lime-and-ash with oak wood } \\
\hline \multirow[t]{5}{*}{ Mole-rat } & $\mathrm{Cu}$ & 0,157 & 0,142 & 1,01 \\
\hline & $\mathrm{Fe}$ & 70,3 & 68,9 & 448 \\
\hline & Mn & 7,44 & 7,26 & 47,5 \\
\hline & $\mathrm{Mg}$ & 80,0 & 84,6 & 510 \\
\hline & $\mathrm{Zn}$ & 0,214 & 0,199 & 1,36 \\
\hline \multirow[t]{5}{*}{ Mice } & $\mathrm{Cu}$ & 0,142 & 0,142 & 0,582 \\
\hline & $\mathrm{Fe}$ & 80,5 & 68,9 & 329 \\
\hline & Mn & 6,24 & 7,26 & 25,5 \\
\hline & $\mathrm{Mg}$ & 96,1 & 84,6 & 393 \\
\hline & $\mathrm{Zn}$ & 0,245 & 0,199 & 0,994 \\
\hline \multicolumn{5}{|c|}{ Artificial oak wood in the watershed } \\
\hline \multirow[t]{5}{*}{ Mole-rat } & $\mathrm{Cu}$ & 0,142 & 0,220 & 0,299 \\
\hline & $\mathrm{Fe}$ & 82,5 & 86,8 & 154 \\
\hline & Mn & 4,55 & 5,92 & 8,36 \\
\hline & $\mathrm{Mg}$ & 125,0 & 111,1 & 705 \\
\hline & $\mathrm{Zn}$ & 0,046 & 0,107 & 0,094 \\
\hline \multicolumn{5}{|c|}{ Humid lime-and-ash with oak wood in floodplain } \\
\hline \multirow[t]{5}{*}{ Mole } & $\mathrm{Cu}$ & 0,126 & 0,142 & 0,378 \\
\hline & $\mathrm{Fe}$ & 38,3 & 63,0 & 102 \\
\hline & Mn & 1,55 & 6,92 & 4,06 \\
\hline & $\mathrm{Mg}$ & 54,9 & 67,2 & 63,8 \\
\hline & $\mathrm{Zn}$ & 0,229 & 0,229 & 0,724 \\
\hline \multirow[t]{5}{*}{ Mice } & $\mathrm{Cu}$ & 0,110 & 0,142 & 0,315 \\
\hline & $\mathrm{Fe}$ & 57,4 & 63,0 & 142 \\
\hline & Mn & 8,26 & 6,92 & 20,1 \\
\hline & $\mathrm{Mg}$ & 70,1 & 67,2 & 75,5 \\
\hline & $\mathrm{Zn}$ & 0,352 & 0,229 & 1,02 \\
\hline \multicolumn{5}{|c|}{ Middle-dry pine wood on sandy terrace } \\
\hline \multirow[t]{5}{*}{ Mole } & $\mathrm{Cu}$ & 0,094 & 0,142 & 0,094 \\
\hline & $\mathrm{Fe}$ & 25,3 & 46,3 & 21,0 \\
\hline & $\mathrm{Mn}$ & 3,20 & 5,04 & 2,49 \\
\hline & $\mathrm{Mg}$ & 19,6 & 48,3 & 7,07 \\
\hline & $\mathrm{Zn}$ & 0,061 & 0,138 & 0,063 \\
\hline
\end{tabular}

The Commentary. Statistically significant exceeding of elements quantity in the pair control-experiment is marked in the table by pattern.

Important way of mammal fossorial activity is geochemical activity and participation in biological cycle of organic matter (Покаржевский, 1985). Geochemical activity of different terrestrial animals is not identical and 
depends from ecological peculiarities of specie and from habitat-transforming improving to components of ecosystem. According with results of native observes and analytical data it is possible to define content of main and diffused elements that gets on the ground cover of different forest ecosystems during a year (the theoretical limit between these groups is 0.1 mass \%). In the Table 1 is shown the middle total content (total chemical quantity) of chemical elements which involved by fossorial mammals into global biological cycle during one year. Thus, the most total quantity of chemical elements gets on the surface as a result of fossorial activity of mole-rat and mice at gully oak wood. In these condition is observed mostly intensive migration of chemical elements per one year. The most slow migration of elements under influence of fossorial activity is typical for sandy soils of middle-dry pine wood on sandy terrace because sandy soils are impoverishing by microelements in comparison with chernozem soils of gullies, watershed and alluvial soils of river floodplains.

\section{CONCLUSIONS}

Fossorial activity of mammals is conductive to trace of microelements from more deep soil horizons into zone of its active involving to biological cycle. It was established by the result of researches that the mostly intensive migration of micro- and macroelements -that is goes at the expense of mammal fossorial activity- is typical for humid gully lime-and-ash with oak wood. A middle position in speed of entering chemical elements is belonging to artificial oak wood in the watershed and humid lime-and-ash with oak wood in floodplain. Mostly slow migration in speed of entering elements is typical for middle-dry pine wood on sandy terrace.

The data showed about the influence of activity small fossorial mammals are demonstrated that it is very important biotical factor in the making chemical regime of wood edaphotopes which is determining the character of matter cycle in ecosystem.

\section{References}

Grulich I. Zweni rostlinnych spolocnstey na lukach vliven ryci cinnosti krtka obecheho (Talpa europaea) v podmi nkach Jizni. Moravy, Preslia. - 1958. - № 30, № 4 .

Абатуров Б. Д. Млекопитающие как компонент экосистемы (на примере растительноядных млекопитающих в полупустыне). - М: Наука, 1984. - 286 с.

Абатуров Б. Д., Карпачевский Л. О. Роющая деятельность крота и её роль в почвообразовании в широколиственно-еловых лесах Московской области // Проблемы почвенной зоологии. - М.: Наука, 1966а. - С. 8-10.

Абатуров Б. Д., Зубкова Л. В. Влияние малых сусликов (Citellus pygmaeus Pall) на водно-физические свойства солонцовых почв полупустыни Заволжья // Почвоведение. - 1969. - № 10. - С. 59-69.

Зубкова Л. В. Влияние выбросов малых сусликов на химические свойства солончаковых солонцов глинистой полупустыни Заволжья // Почвоведение. - 1971. - № 4. - С. 73-80.

Иванов В. В. Малый суслик - рассолонитель почв // Известия Всесоюз. географ. об-ва. - 1950. - Т. 82, вып. 5. - С. 551-553.

Pakhomov A. Ye., Belokon A. S. Fossorial activity of mola rat and migration of caesium-137 and strontium-90 in soils of Ukraine steppe forests // Sustainable Development: system analysis in ecology. 2nd Practical conference (Sevastopol, Ukraine, September, 9-12, 1996). Conference abstracts. - Севастополь: Севастопольський держ. техніч. ун-т, 1996. - С. 146-147.

Пахомов А. Е., Подьячева И. В., Галкин А. С. Роющая деятельность микромаммалий как фактор в снижении суммарной $\beta$ радиоактивности почв байрачных дубрав степных лесов Украины // Экология и молодежь: Материалы 1 Междунар. науч.практ. конф. - Гомель, 1998. -Т. 1, ч. 2. - С. 120-121.

Гиляров М. С. Роль степных грызунов в происхождении полевой почвенной энтомофауны и сорно-полевой растительности // Докл. АН СССР. Нов. сер. - 1951. - Т. 76, вып. 4. - С. 669-671.

Кучерук В. В. Воздействие травоядных млекопитающих на продуктивносить травостоя в степи и их значение в образовании органической части степных почв // Биология, биогеоценология и систематика млекопитающих СССР. - М.: Изд-во АН СССР, 1963. - C.157-193.

Reva A. A., Bulakhov V. L., Micheyev A.V., Pakhomov A. Ye. Mammalia excrete and burrowing activity as ecological factor in the system of soil protective responses under cadmium pollution // Second International symposium ISMOM 96, Effect of mineral-organicmicroorganism Interactions on soil and freshwater environments. 3-6 sept. 1996. Nancy-France. - 1996. - P. 103.

Пахомов А. Е. Позвоночные-почворои как экологический фактор в формировании эдафотопного блока в лесных биогеоценозах степной зоны Украины // Охорона довкілля: екологічні, медичні освітянські аспекти: Матеріали Всеукр. конф. - Кривий Ріг, 1997a. - Ч. 1. - C. 68-69.

Koide R. T., Huenneke L. F., Mooney H. A. Gopher mound soil reduces growth and affects ion uptake of two annual grassland species // Oecologia. - 1987. - 72, № 2. - P. 284-290.

Carlson D. C., White E. M. Variations in surface-layer color, texture, pH and phosphorus content across prairie dog mounds // Soil Sci. Soc. Amer. J. - 1988. - № 6. - P. 1758-1761.

Пахомов А. Е. Влияние роющей деятельности крота на перераспределение микроэлементов в пойменных лесных биогеоценозах Степного Приднепровья // Всесоюз. совещ. по биологии насекомоядных млекопитающих, 4-7 февр. 1992 г., Новосибирск. - М., 1992. - C. 133-134. 
Pakhomov A., Bulakhov V. Trace elements migration in soil-herbaceous plant system under animals fossorial activity // Contaminated soils / Third international conference on the biogeochemistry of Trance elements. 15-19 May 1995. Paris-France. T. B. Impactsand Pathways of Exposure. B. 1. 1995. Paris-France. - P. 110.

Bulakhov V. L. Vertebrates Role in metals transformation intensification in steppe forests soil of Ukraine. Extended abstracts Fourth International conference on the biochemistry of Trace elements. June 23-26, 1997, Clark Kerr. Campus. University of California. Berkeley, California. - P. 371-372.

Pakhomov A.Ye. Rodentia - soil Burrowers influence on ash content in the "Soil-Plant" system in the steppe oak-groves of Ukraine // Proceedings of Extended Asbstracts from the Fourth international conference on the biogeochemistry of Trance elements. June 23-26, 1997. Clare Kerr Campus Berkeley, California, USA, 1997. - P. 65-66.

Pakhomov A.Ye. Mammals role in selfpurification of soil from pollution // Secotox 97. Abstracts. Ecotoxicology and Environmental Safety Central Eastern European Conference. 24-27 August.1997. Jurmala-Latvia. - 1997a. - P. 205.

Покаржевский А. Д. Геохимическая экология наземных животных. - М.: Наука, 1985. - 304 с. 